\title{
Az étrend szerepe a húgyúti kövek kialakulásában és megelőzésében
}

\author{
Szendrői Attila dr. ${ }^{1}$. Tordé Ákos dr. ${ }^{1}$ \\ Vargha Judit dr. ${ }^{1}$ - Bánfi Gergely dr. ${ }^{1}$ - Horváth András dr. ${ }^{1}$ \\ Horváth Csaba dr. ${ }^{2^{*}}$ - Nyirády Péter $\mathbf{d r} .^{1^{*}}$
}

${ }^{1}$ Semmelweis Egyetem, Általános Orvostudományi Kar, ${ }^{1}$ Urológiai Klinika, ${ }^{2}$ I. Belgyógyászati Klinika, Budapest

\begin{abstract}
A húgyúti kövesség a fejlett országokban a metabolikus és endokrin okok mellett egyre gyakrabban fordul elő a helytelen táplálkozási szokások, az elhízás és a mozgásszegény életmód miatt. Ezért az urológusok és az alapellátásban dolgozók mindennapi munkájában kiemelt szerepet kellene, hogy kapjon az elsődleges és másodlagos prevenció. A megelőzés a testsúlykontrollon, a testmozgáson és a gyógyszeres kezelésen túl a megfelelő diétán alapul. Az étrend különböző alkotóelemei megváltoztathatják a vizelet összetételét és ezáltal annak túltelítettségét fokozhatják, amely alapja a kőképződésnek.

Az étrendi összetevők vagy elősegítik a kövesség megelőzését (fokozott folyadékbevitel, citrát, magnézium, gyümölcsök és zöldségek), vagy hajlamosítóan hatnak annak kialakulására (kevés folyadékbevitel, fehérjében, szénhidrátban, zsírban, oxalátban, sóban, kalciumban gazdag étrend, aszkorbinsav stb.).

Összefoglalónkban bizonyítékokkal alátámasztott étrendi javaslatokat fogalmaztunk meg, amelyek a húgyúti kövesség elsődleges és másodlagos megelőzésében gyakorlati haszonnal bírnak.
\end{abstract}

Orv Hetil. 2017; 158(22): 851-855.

Kulcsszavak: húgyúti kövesség, étrendi szokások, kockázati tényezők, megelőzés

\section{Role of the diet in urinary stone formation and prevalence}

In Hungary and in the developed countries urinary stones occur more often due to nutritional habits, obesity and sedentary lifestyle beside the endocrine and metabolic causes. In the daily urological and family doctor practice prevention should have an important role. Prevention is based not only on body weight control, physical exercise and medical treatment, but on proper diet as well. The nutritional components can change the consistence of urine, causing supersaturation, which is essential in stone formation.

Specific nutritional components can either prevent stone formation (increased fluid intake, citrate, magnesium, fruits and vegetables) or either increase stone formation (decreased fluid intake, proteins, carbohydrates, oxalate, salt, increased calcium intake, ascorbic-acid etc).

We summarized evidence-based practical dietary suggestions on the primary and secondary prevention of urinary stones.

Keywords: urinary calculi, nutritional habits, risk factors, prevention

Szendrői A, Tordé Á, Vargha J, Bánfi G, Horváth A, Horváth Cs, Nyirády P. [Role of the diet in urinary stone formation and prevalence]. Orv Hetil. 2017; 158(22): 851-855.

(Beérkezett: 2017. február 27.; elfogadva: 2017. április 16.)

*A szerzők egyenlő módon vették ki részüket a dolgozat felügyeletében és szerkesztésében.

A fejlett országokban, így hazánkban is, a húgyúti kövesség incidenciája egyre növekszik [1]. Ebben a modern, nyugati életforma, a mozgásszegény életmód, az elhízás és az étrend is jelentős szereppel bír, ezen utóbbi alapve- tően meghatározza a vizelet összetételét [2]. Meg kell említenünk, hogy habár a húgyúti kövesség a fejlettebb társadalmakban egyre gyakoribb megbetegedés, a vese üregrendszerét szinte teljesen kitöltő korallkövek inci- 
denciája itt csökken (10-20\% vs. 4\%) [3]. A kőbetegség hátterének tanulmányozását nehezíti, hogy egyszerre számtalan környezeti (külső hőmérséklet, az elfogyasztott víz összetétele stb.), életmódbeli (ruházat, testmozgás, táplálkozás, testsúly stb.), genetikai és egyéb tényező́t kellene figyelembe venni a vizsgálatok során, amelyek gyakran szoros kölcsönhatásban állnak egymással. Az étrend egyes tényezőivel kapcsolatban hosszú távú, randomizált, követéses vizsgálatok mutatták ki hatásukat a kőképződésre, más összetevők esetén csak rövid távú klinikai vagy anyagcsere-vizsgálatok állnak rendelkezésre. Összefoglalónkban áttekintjük az irodalomban az étrend egyes összetevőinek szerepét a primer és a visszatérő kőbetegség kialakulásával kapcsolatban. A fentiekből következik, hogy a kövesség megelőzéséhez nem elegendó egy-egy diétás tanács megfogadása: teljes szemlélet- és életmódváltásra van szükség. Munkánkkal útmutatót kívánunk nyújtani a hétköznapi gyakorlatban a köves betegek kezeléséhez, életmódbeli és diétás tanácsadásához.

\section{Folyadékbevitel}

Számos vizsgálat során bizonyították, hogy napi 2,5 liter vizeletürítés esetén csökken a vizeletben a kalciumsó túltelítettsége $[4,5]$. Ez azt jelenti, hogy vesekövességben szenvedő betegek esetén a kevés folyadékbevitel jelentős kockázati tényező a kő kialakulásának szempontjából. Általánosságban véve elmondható, hogy napi 2,5 liter vizeletürítés javasolt, és ha ez kevesebb, mint $1000 \mathrm{ml} /$ nap, akkor jelentősen növelni kell a folyadékbevitelt [4, 5]. Vízen kívül lehet teát, kávét, bort, sört és gyümölcsitalt is fogyasztani, ezeket azonban mértékkel. A szénsavas üdítóitalok fogyasztása kerülendő, hasonlóan a paradicsomot, grépfrútot és áfonyát tartalmazó italokhoz, mert ezek oxaláttartalma magas [6-8].

\section{Fehérjebevitel}

Az állati fehérjét tartalmazó étrend mobilizálja a csontban lévő kalciumot [9]. A purintúltelítettség megemeli a húgysav- és annak anyagcsere-melléktermékének, az oxalátnak a szintjét. Ezáltal acidosis jön létre, amely a citrátnak a tubularis sejtekbe történő bejutását idézi elő, hypocitruriát és vizelet-pH-csökkenést eredményezve. A fentiek összességükben tehát növelik a vizelet kalciumszintjét, valamint növelik az oxalát és a húgysav vizeletben történő kiválasztását is, valamint csökkentik a kristályosodást gátló citrát koncentrációját és savanyítják a vizeletet [10-12].

Ezek a tényezők kedveznek a kalciumtartalmú és húgysavkövek kialakulásának, ezért a kalciumtartalmú vagy húgysavkövességben szenvedő betegek részére kevesebb állati fehérjebevitel javasolt. Az ajánlott fogyasztás: naponta két adag, mértéke: körülbelül $0,8-1 \mathrm{~g} / \mathrm{kg} /$ nap, vagyis 91 gramm fehérje naponta, ebből 21 gramm legyen állati eredetú, a többi pedig tej vagy tejtermék, kenyér, tészta és zöldségfélék [13-15].
Fehérjében gazdag állati eredetû́ élelmiszernek minősül a vörös hús (marha, sertés, bárány, kecske), olajos hal, tengeri kagyló, felvágottak, húsleves, valamint a belsőségek.

\section{Nátriumbevitel}

A fokozott sóbevitel (nátrium-klorid) a sejten kívüli folyadék térfogatának növekedését eredményezi, és csökkenti a kalcium tubularis reabszorpcióját. Ez megnövekedett vizeletkalcium-szintet idéz elő, és enyhe metabolikus acidosist okoz hypocitruriával. A diétában minden egyes extra $100 \mathrm{mmol}$ só $25-40 \mathrm{mg}$ közötti vizeletkalciumszint-emelkedést jelent egy 24 órás periódusban [16]. Egészséges ember esetén 6 g-mal több sófogyasztás a vizelet kalciumszintjét $40 \mathrm{mg}$-mal emeli meg, míg a kövességben szenvedő betegnél 80 mg-mal. Általános javaslat, hogy a sóbevitel mennyisége ne haladja meg az 5-6 grammot 24 órán belül [17]. Jóllehet, a sóbevitel csökkentése alacsonyabb vizeletkalcium-szintet eredményez, mégis felnőttek esetén ritka, hogy a magas sóbevitel lenne az egyetlen oka az idiopathiás hypercalciuriának [16].

\section{Kalciumbevitel, tejtermékek és származékai}

A hypercalciuriában szenvedó betegek esetén a kalcium bélben történő felszívódása fokozott, ezért régebben ezeknek a betegeknek a kalciumbevitel csökkentését ajánlották [18]. A kőkiújulás megelőzésének céljából a kalciumbevitel étrendi csökkentése, a köves betegségben szenvedő népesség széles körében végzett epidemiológiai vizsgálatok evidenciája alapján, napjainkban már nem javasolt. Egy - a betegeket öt éven keresztül nyomon követő - prospektív vizsgálat megállapította, hogy az alacsony kalciumtartalmú étrendnek nincs jelentősége a kőmegelőzésben [19]. Az alacsony kalciumtartalmú étrend ugyanakkor egy másik problémával is jár: felgyorsítja a csont ásványi sứrüségének nagyobb ütemú csökkenését a menopauza után lévő nők esetében, negatív kalciumegyensúlyt hozva létre a csontokban [20]. Ráadásul az alacsony kalciumtartalmú étrend miatt a bélben kevés lesz a kalcium. Ez kedvez annak, hogy az oxalát kötetlen formában maradjon a bélben, amelynek eredménye a megnövekedett oxalátabszorpció, és ezáltal a vizeletben megnövekszik annak kiválasztódása is. Az elégtelen kalciumbevitel az étrendben tehát másodlagos hyperoxaluriához vezethet [21]. Mindezek mellett a hypercalciuria hátterében gyakrabban igazolódik renalis eredet, mint nem megfeleló étrend. Renalis kalciumvesztés esetén a táplálékkal bevitt kalcium megszorításának nincs létjogosultsága. Általánosságban véve a kalciumbevitel javasolt mennyisége naponta 1000-1200 mg [22].

A különböző ételek kalciumtartalmát az 1. táblázatban foglaltuk össze. 
1. táblázat |Ételeink kalciumtartalma

\begin{tabular}{lc}
\hline Étel & Kalciumtartalom $(\mathrm{mg} / 100 \mathrm{~g})$ \\
\hline Zsíros/félzsíros tej & $125-135$ \\
Lágy sajt & $180-200$ \\
Túró & $100-110$ \\
Joghurt & $150-200$ \\
Sodó/tejkaramell/tejszín & $150-300$ \\
Hal & $50-100$ \\
Konzerv szardínia & $350-500$ \\
Folyami rák, garnélarák & $200-220$ \\
Kagyló & $100-120$ \\
Tojás & $40-50$ \\
Tészta & $50-90$ \\
Bab, csicseriborsó & $130-150$ \\
Zöldbab, káposzta, articsóka & $40-50$ \\
Fehérrépa, spenót, póréhagyma & $100-110$ \\
Dió, mandula & $100-250$ \\
Olajbogyó & $50-60$ \\
\hline
\end{tabular}

\section{Szénhidrátbevitel}

Tanulmányok igazolják, hogy a glükóztúlterhelés a kövességben szenvedő betegek esetében nagyobb kalciumkiválasztással jár, mint a vesekövességben nem szenvedő betegeknél, valamint azt is, hogy a vércukorszint megfelelő kontrollja csökkentheti az ürített kalcium mennyiségét [23]. Ezért a szénhidrátbevitel szoros kontrollja javasolt húgyúti kövességben szenvedő betegeknél. A fokozott szénhidrátbevitel nemcsak elősegíti a vizeletben ürített kalciumszint növekedését, hanem az inzulinrezisztencia megjelenése miatt nő a metabolikus szindróma kialakulásának kockázata is. Néhány tanulmány megállapította, hogy közvetlen összefüggés van a magasabb testtömegindex (BMI) és a megnövekedett kalcium-, oxalát- és húgysavkiválasztás, valamint az alacsonyabb vizelet-pH között [23]. Ezen betegek között magasabb arányban fordul eló húgysavkő. Ennek a ténynek az lehet a magyarázata, hogy az inzulinrezisztencia, amely elsősorban túlsúlyos betegeknél fordul elő, kapcsolatba hozható azzal, hogy a vesék ammóniakiválasztása csökkent, így a test sav-bázis egyensúlya nem kellóképpen szabályozott, és a vizelet savmerevségre hajlamos [24]. Savmerevnek nevezzük a beteg vizeletét, amennyiben több különböző alkalommal ürített vizelet közül egynek a pH-ja sem haladja meg az 5,2-et.

Figyelembe véve azt a szoros összefüggést, amely a szénhidrátfogyasztás és az inzulinrezisztencia, a diabetes mellitus és az elhízás között fennáll, feltételezhető, hogy a túlzott szénhidrátfogyasztás a húgyúti kövességben szenvedő betegek esetén kockázati tényező lehet, függetlenül attól, hogy a fenti összefüggések ellenére a közvetlen kapcsolatot klinikai vizsgálatok még nem erősítették meg.

\section{Zsírbevitel}

Számos tanulmány utal arra, hogy a húgyúti kövességben szenvedő betegek körében gyakoribb a dyslipidaemia, valamint, hogy a lipideknek szerepük van az oxalátkiválasztódás növekedésében, ami telített zsírsavakban és transzzsírsavakban (például arachidonsav) gazdag étel fogyasztása esetén még kifejezettebb [25-27]. Az arachidonsav a prosztaglandin-E2-szint növekedését okozza, ami hozzájárul a hypercalciuria kialakulásához, és elősegíti a csontállomány kalciumvesztését [28]. A telítetlen zsírok (például eikoza-penténsav) fokozott bevitele ellenben azt eredményezi, hogy a prosztaglandin-E2 szintje csökken, ami nemcsak csökkent vizeletkalciumkiválasztáshoz vezet, hanem ennek az anyagnak a tubulusokban történő fokozott felszívódásához is $[29,30]$. Az eikoza-penténsav megtalálható az alábbi élelmiszerekben: olajos hal, lazac, tonhal, makréla, szardínia, valamint dió és lenmag [31].

\section{Oxalátban gazdag ételek fogyasztása}

A vizeletben kiválasztódott oxalát kevésbé a táplálékkal felszívódott oxalát mennyiségétől függ, sokkal inkább az egyén szervezetében keletkezett oxalátmetabolizmus terméke [32]. Az oxalátban gazdag ételek kerülése csak azoknak a betegeknek hasznos, akik a bélen keresztüli oxalát-hiperabszorpció miatt szenvednek hyperoxaluriában [32]. Ekkor javasolják, hogy csökkentsék az oxalátban gazdag ételek, mint spenót, rebarbara, petrezselyem, snidling, répalevél, zöld tea és csokoládé bevitelét [33, 34]. Hyperoxaluria esetén vizsgálatok tárgyát képezi az egészséges bélmikroflórát biztosító, az oxalát lebontásáért felelős anaerob Oxalobacter formigenes szerepe. Tevékenysége következtében csökken az oxalátfelszívódás, ami előmozdítja a hyperoxaluria csökkenését, ezért a későbbiekben probiotikumként történő alkalmazása előnyös lehet a visszatérő kövesség megelőzésében [35]. $\mathrm{A} \mathrm{B}_{6}$-vitaminnal kapcsolatban megfigyelték, hogy csökkent oxalátkiválasztást idéz elő és ezért hasznos a kalcium-oxalát-kövességben szenvedő betegeknek [36, 37].

2. táblázat | Étrendi javaslatok

\begin{tabular}{ll}
\hline Táplálék, folyadék & Napi bevitel \\
\hline Folyadék & 2,5 liter \\
Állati fehérje & $0,8-1 \mathrm{~g} / \mathrm{ttkg}$ \\
Sóbevítel & $3-5 \mathrm{~g}$ \\
Szénhidrát & $125-150 \mathrm{~g}$ \\
Kalcium & $1000-1200 \mathrm{mg}$ \\
Telített zsír & Nem javasolt \\
Transzzsírsavak & Nem javasolt \\
Telítetlen zsírsavak & Javasolt \\
Zöldség, gyümölcs & Javasolt \\
\hline
\end{tabular}




\section{Gyümölcs- és zöldségbevitel}

Általánosságban véve a gyümölcsök és a zöldségek alacsony protein- és nátrium-klorid-tartalmúak, gazdagok káliumban és magnéziumban, valamint bikarbonát- és citráttartalmuknak köszönhetően természetes lúgosító hatásúak. Ezen tulajdonságoknak köszönhetően a gyümölcs- és zöldségfogyasztás csökkentheti a húgyúti kövesség kialakulását, mert a kalcium és a húgysav kristályosodását gátló citrát és a magnézium szintje ekkor magasabb a vizeletben, valamint a vizelet $\mathrm{PH}-\mathrm{ja}$ is magasabb $[38,39]$.

\section{Vitaminbevitel}

Jelentős D-vitamin-bevitel esetén, amely kalciummal kiegészítve az osteoporosisban szenvedő betegeknél gyakori terápiás előírás, a nephrolithiasis kockázata megnövekedhet, ezért kivételes esetektől eltekintve ez nem javasolt azon betegeknél, akiknek a kórelőzményében húgyúti kövesség fordult elő [40]. A C-vitamin fokozott bevitele a média hatására igen elterjedt az utóbbi évtizedekben, nem ritka a napi szükséglet több mint tízszeresét jelentő 1000 mg-os javaslat. A felesleges C-vitamin a vizeletbe választódik ki, és fokozza az oxalátürítést, ezáltal a kőbetegség kialakulásában jelentős szereppel bír. Azoknak a betegeknek, akiknek kalcium-oxalát köve volt, a túlzott C-vitamin-fogyasztás mindenképpen káros $[41]$ !

\section{Általános étrendi tanácsok kövességben szenvedő betegeknek}

Attól függetlenül, hogy a kövességnek sokféle fajtája van és mindegyiknek megvan a megelőzést biztosító étrend vonatkozásában a sajátos jellegzetessége, a húgyúti kövességben szenvedő betegek esetén mégis megfogalmazható néhány általános étrendi javaslat [42]:

- Megfelelő folyadékbevitel, hogy fenntartsuk a megfelelő, több mint 2,5 liter/nap vizeletürítést. A folyadékbevitel növelendő jelentős vizeletvesztés, izzadás, testmozgás estén.

- Az állatifehérje-bevitel legfeljebb 0,8-1 g/ttkg/napra korlátozódjon, mert a túlzott fehérjefogyasztás elősegíti a hypocitruria, a hyperoxaluria és a hyperuricosuria kialakulását és csökkenti a vizelet $\mathrm{pH}$-ját.

- A sóbevitel ne haladja meg a napi 3-5 g-ot!

- A nagy mennyiségú szénhidrátbevitel kerülendő, mivel ez növeli a vizelet kalciumszintjét és csökkenti a citrátszintet.

- Tejtermékek és származékaik fogyasztása javasolt a napi kalciumbevitelhez, amelynek mennyisége 1000$1200 \mathrm{mg} / 24$ óra legyen!

- A telített zsírok és transzzsírsavak fogyasztása kerülendő, viszont a halolajban nagyobb mennyiségben lévő eikoza-penténsav fogyasztása javasolt.
- Gyümölcs- és zöldségfogyasztás javasolt, mert ezek citrátot és magnéziumot tartalmaznak és a túltelített vizelet kristályosodását gátolják.

- Az étrend összetevőinek helyes aránya mellett a menynyiség legalább annyira fontos: a mértékletes, változatos étrend a követendő út [43]. Fontos kiemelni, hogy a helyes étrenddel és életmóddal sem kerülhető el minden esetben a kőbetegség visszatérése, hiszen gyakran annak hátterében anyagcsere-, illetve egyéb eltérések állnak.

- A köves beteg számára javasolt általános étrendi javaslatokat a 2. táblázatban foglaltuk össze.

\section{Speciális étrendi javaslatok}

Fontos, hogy a kövességben szenvedő betegek vonatkozásában az anyagcsere-eltérésekre irányuló kivizsgálást követően további speciális intézkedéseket is tegyünk, mivel az étrend módosításával az eltérésekre vagy a kőképződési tényezőkre hatni tudunk:

- Hyperoxaluria esetén a $\mathrm{B}_{6}$-vitamin-bevitel tanácsos, de az oxalátban dús ételek (tea, kóla, kakaó, cikória, articsóka, spenót, fehérrépa, cékla, dió, zöldborsó, eper, szárított gyümölcs és citrusfélék, különösen a grépfrút) kerülendők. A tej és tejtermékek fogyasztása javasolt, hiszen a kalcium-oxalát kelátképző, és ezáltal megelőzi a bélben történő oxalátfelszívódást.

- Abszorpciós hypercalcuria esetén kevesebb javasolt az alábbi élelmiszerekből: tejtermék, bab, csicseriborsó, konzervhal és tenger gyümölcsei.

- Hyperuricosuria esetén csökkentendő az alábbi ételek fogyasztása: olajos hal, tenger gyümölcsei, felvágott, belsőségek; a zöldségek közül: karfiol, spárga, gomba. A citrusos italok és a lúgos ásványvíz fogyasztása ajánlott, de csak az alacsony szárazanyag-tartalmúé. Az alkoholtartalmú italok kerülendők.

- Cystinuria esetén a citrusos italok és az alacsony nátriumtartalmú ásványvíz fogyasztása növelendő, valamint mérsékelt só- és állatifehérje-bevitel javasolt.

Anyagi támogatás: A szerzók anyagi támogatásban nem részesültek.

Szerzői munkamegosztás: Sz. A., T. Á., V. J., B. G., H. A.: A kézirat szövegezése, irodalmazás. H. Cs., Ny. P.: A munka összefogása, irányítása, a kézirat ellenőrzése. A cikk végleges változatát valamennyi szerző elolvasta és jóváhagyta.

Érdekeltségek: A szerzőknek nincsenek érdekeltségeik.

\section{Köszönetnyilvánítás}

A cikk szerzői köszönetet mondanak Magyaródi Ágnesnek az irodalmazásban és a szöveg szerkesztésében nyújtott segítségéért. 


\section{Irodalom}

[1] Scales CD, Smith AC, Hanley JM, et al. Prevalence of kidney stones in the United States. Eur Urol. 2012; 62: 160-165.

[2] Curhan GC, Willett WC, Speizer FE, et al. Twenty-four-hour urine chemistries and the risk of kidney stones among women and men. Kidney Int. 2001; 59: 2290-2298.

[3] Berczi Cs, Varga A, Tállai B, et al. Percutaneous nephrolithotomy in elderly and in younger patients. [Az idős és a fiatalabb korosztályban végzett percutan vesekó-eltávolítás.] Magyar Urológia. 2011; 23: 61-66. [Hungarian]

[4] Siener R, Hesse A. Fluid intake and epidemiology of urolithiasis. Eur J Clin Nutr. 2003; 57(Suppl 2): 47-51.

[5] Borghi L, Meschi T, Schianchi T, et al. Urine volume: stone risk factor and preventive measure. Nephron. 1999; 81(Suppl 1): 31-37.

[6] Curhan GC, Willett WC, Rimm EB, et al. Prospective study of beverage use and the risk of kidney stones. Am J Epidemiol. 1995; 143: 240-247.

[7] Schuster J, Jenkins A, Logan C, et al. Soft drink consumption and urinary stone recurrence: a randomized prevention trial. J Clin Epidemiol. 1992; 45: 911-916.

[8] Curhan GC, Willett WC, Speizer FE, et al. Beverage use and risk for kidney stones in women. Ann Intern Med. 1998; 128: 534540

[9] Kerstetter JE, O'Brien KO, Caseria DM, et al. The impact of dietary protein on calcium absorption and kinetic measures of bone turnover in women. J Clin Endocrinol Metab. 2005; 90: 26-31.

[10] Licata AA, Bou E, Bartter FC, et al. Effects of dietary protein on urinary calcium in normal subjects and in patients with nephrolithiasis. Metab Clin Exp. 1979; 28: 895-900.

[11] Hunt JR, Johnson LK, Fariba Roughead ZK. Dietary protein and calcium interact to influence calcium retention: a controlled feeding study. Am J Clin Nutr. 2009; 89: 1357-1365.

[12] Maalouf NM, Moe OW, Adams-Huet B, et al. Hypercalciuria associated with high dietary protein intake is not due to acid load. J Clin Endocrinol Metab. 2011; 96: 3733-3740.

[13] Gul Z, Monga M. Medical and dietary therapy for kidney stone prevention. Korean J Urol. 2014; 55: 775-779.

[14] Nouvenne A, Meschi T, Guerra A, et al. Dietary treatment of nephrolithiasis. Clin Case Miner Bone Metab. 2008; 5: 135141

[15] Borghi L, Meschi T, Maggiore U, et al. Dietary therapy in idiopathic nephrolithiasis. Nutr Rev. 2006; 64: 301-312.

[16] Nouvenne A, Meschi T, Prati B, et al. Effects of a low-sodium diet on idiopathic hypercalciuria in calcium-oxalate stone formers: a 3-mo randomized controlled trial. Am J Clin Nutr. 2010 91: $565-570$.

[17] Worcester EM, Coe FL. New insights into the pathogenesis of idiopathic hypercalciuria. Semin Nephrol. 2008; 28: 120-132.

[18] Soltész I, Mihály T, Lakatos B. Prevention of calcium-oxalate stone formation. [A Ca-oxalát-kőképződés megelőzése.] Magyar Urológia. 1990; 2: 337-343. [Hungarian]

[19] Bataille P, Presne C, Fournier A. Prevention of recurrent stones in idiopathic hypercalciuria. N Engl J Med. 2002; 346: 16671669.

[20] Heilberg IP, Goldfarb DS. Optimum nutritio for kidney stone disease. Adv Chronic Kidney Dis. 2013; 20: 165-174.

[21] Trinchieri A. Diet and renal stone formation. Minerva Med. 2013, 104: 41-54.

[22] Curhan GC, Willett WC, Rimm EB, et al. A prospective study of dietary calcium and other nutrients and the risk of symptomatic kidney stones. N Engl J Med. 1993; 328: 833-838.

[23] Sakhaee K. Recent advances in the pathophysiology fo nephrolithiasis. Kidney Int. 2009; 75: 585-595.
[24] Hatch M, Schepers A, Grunberger I, et al. A retrospective analysis of the metabolic status of stone formers in the New York city metropolitan areas. NY State J Med. 1991; 91: 196-200.

[25] Schmiedl A, Schwille PO, Bonucci E, et al. Nephrocalcinosis and hyperlipidemia in rats fed a cholesterol- and fat-rich diet: association with hyperoxaluria, altered kidney and bone minerals, and renal tissue phospholipid-calcium interaction. Urol Res. 2000, 28: 404-415.

[26] Khan SR, Glenton PA, Backov R, et al. Presence of lipids in urine, crystals and stones: implications for the formation of kidney stones. Kidney Int. 2002; 62: 2062-2072.

[27] Naya $Y$, Ito $H$, Masai $M$, et al. Association of dietary fatty acids with urinary oxalate excretion in calcium oxalate stone-formers in their fourth decade. BJU Int. 2002; 89: 842-846.

[28] Taylor EN, Stampfer MJ, Curhan GC. Fatty acid intake and incident nephrolithiasis. Am J Kidney Dis. 2005; 45: 267-274.

[29] Yasui T, Tanaka H, Fujita K, et al. Effects of eicosapentaenoic acid on urinary calcium excretion in calcium stone formers. Eur Urol. 2001; 39: 580-585.

[30] Buck AC, Davies RL, Harrison T. The protective role of eicosapentaenoic acid [EPA] in the pathogenesis of nephrolithiasis. J Urol. 1991; 146: 188-194.

[31] Grases F, Costa-Bauza A, Prieto RM. Renal lithiasis and nutrition. Nutr J. 2006; 5: 23-29.

[32] Krishnamurthy MS, Hruska KA, Chandhoke PS. The urinary response to an oral oxalate load in recurrent calcium stone formers. J Urol. 2003; 169: 2030-2033.

[33] Taylor EN, Curhan GC. Oxalate intake and the risk for nephrolithiasis. J Am Soc Nephrol. 2007; 18: 2198-2204.

[34] Antonelli JA, Langman CB, Odom C, et al. Defining variation in urinary oxalate in hyperoxaluric stone formers. J Endourol. 2013; 27: 1530-1534.

[35] Sidhu H, Schmidt ME, Cornelius JG, et al. Direct correlation between hyperoxaluria/oxalate stone disease and the absence of the gastrointestinal tract-welling bacterium Oxalobacter formigenes: possible prevention by gut recolonization or enzyme replacement therapy. J Am Soc Nephrol. 1999; 10(Suppl): S334S340.

[36] Frassetto L, Kohlstadt I. Treatment and prevention of kidney stones: an update. Am Fam Physician. 2011; 84: 1234-1242.

[37] Yuvanc E, Yilmaz E, Tuglu D, et al. Medical and alternative therapies in urinary tract stone disease. World J Nephrol. 2015; 4: 492-499.

[38] Meschi T, Maggiore U, Fiaccadori E, et al. The effect of fruits and vegetables on urinary stone risk factors. Kidney Int. 2004; 66: 2402-2410.

[39] Baia DC, Baxmann AC, Moreira SR, et al. Noncitrus alkaline fruit: a dietary alternative for the treatment of hypocitraturic stone formers. J Endourol. 2012; 26: 1221-1226.

[40] Leaf DE, Korets R, Taylor EN, et al. Effect of vitamin D repletion on urinary calcium excretion among kidney stone formers. Clin J Am Soc Nephrol. 2012; 7: 829-834.

[41] Nguyen S, Baggerly L, French C, et al. 25-hydroxyvitamin D in the range of 20 to $100 \mathrm{ng} / \mathrm{mL}$ and incidence of kidney stones. Am J Public Health. 2013; 104: 1783-1787.

[42] Keszthelyi A, Hamvas A. Prevention of kidney stone disease. [A vesekőbetegség prevenciója.] Családorvosi Fórum. 2002; 3 : 22-23. [Hungarian]

[43] Berényi M. Prevention. In: Berényi M. Urolithiasis. [Megelőzés: In: Berényi M. Urolithiasis, vesekőbetegség.] Medicina Könyvkiadó, Budapest, 1981; pp. 194-206. [Hungarian]

(Szendrői Attila dr., Budapest, Üllői út 78/B, 1082 e-mail: aszendroi@gmail.com) 